\title{
Utilization Management of Landfill Zones Based on Volume of Municipal Organic Waste Simulation
}

\author{
Philip Faster Eka Adipraja ${ }^{1}$, Mufidatul Islamiyah², Ida Wahyuni ${ }^{3}$
}

\begin{abstract}
Talangagung landfill is one of the zones that well managed by the government of Malang Regency which uses sanitary landfill method. Additionally, it's also succeeded in the utilization of methane gas which has already distributed to the residents around the landfill directly from the landfill zones for daily purposes. For a couple of years, the processing of municipal waste in Talangagung is quite well, however, the significant increase in the waste generation could lead to new management problems in the landfill. The models in this study were validated with a small error of E1 about $2.33 \%$ and the error of $\mathrm{E} 2$ about $\mathbf{0 . 7 6 \%}$. The prediction on the waste volume on next 20 years shows that the increased amount of waste volume soon or later will exceed the current capacity of landfill zones. The previous study about waste degradation shows the different time periods of degradation in various waste as fast as just about a month to more than 7 months. The simulation from this study shows that around 2004 require 2 landfill zones to use simultaneously. Hereafter, the prediction shows while in 2018 the landfill requires 3 zones used simultaneously, starts from 2025 there is necessary to use 4 zones simultaneously. Based on the simulation result, the landfill will overload in around 2026.
\end{abstract}

Keywords_-landfill zones optimization, municipal organic waste, simulation, system dynamics, talangagung landfill.

\section{INTRODUCTION}

$\mathrm{T}$ he developing country, Indonesia with its dense population creating a big challenge in municipal waste management. Governments in some cities and districts trying to manage landfill sites using various methods such as sanitary landfill, minimally controlled landfill, and/or open dumping. Other managements starts intensively on 3R (Reduce, Reuse, and Recycle) and the utilization of the biogas reactor [1].

Talangagung landfill is one of the zones that well managed by the government of Malang Regency which uses sanitary landfill method [2]. Additionally, it's also succeeded in the utilization of methane gas which has already distributed from the landfill directly to the residents around the landfill zones for daily purposes such as cooking [3].

In the last few years, there is an increase in municipal waste which is delivered to Talangagung landfill. The data shows that Talangagung receives as much as 46,558 $\mathrm{M}^{3}$ of municipal waste in 2014 , however, an increase of the volume up to $150 \%$ or as much as $70,490 \mathrm{M}^{3}$ occurred in 2015 [2]. This phenomenon mainly caused by the increase in the number of the resident of Malang about $0.73 \%$ per year [4] along with the increased of residents consumption [5].

For decades, the processing of municipal waste in Talangagung landfill has been done well enough, but the significant increase in waste volume could lead to new problems in the management of landfill zones.

${ }^{1}$ Philip Faster Eka Adipraja is with Department of Informatics Engineering, STMIK Asia Malang, Malang, 65142, Indonesia. E-mail: philipfaster@gmail.com.

${ }^{2}$ Mufidatul Islamiyah is with Departement of Statistics, Institut Teknologi Sepuluh Nopember (ITS), Surabaya, 60111, Indonesia. Email: vitaratna70@gmail.com.

${ }^{3}$ Ida Wahyuni is with Department of Informatics Engineering, STMIK Asia Malang, Malang, 65142, Indonesia. E-mail: ida.wahyuni8@gmail.com
The prediction on yearly waste volume [4] shows that the increased amount of waste volume soon or later will exceed the current capacity of landfill zones.

A various study using system dynamics have been used in modeling and simulating of the municipal waste volume in various countries [4] [6] [7] [8] where these researches are used as references in the modeling and simulation of this study. Modeling and simulation with system dynamic approaches used to analyzing of causal factors, dependencies, mutual interactions, and feedback of information as a method for creating, analyzing, and designing a new policy [9]. Therefore, in this study using system dynamic approach to identify and simulate the organic waste generation and degradation periods with some factor variables that have relevance to optimize the landfill zones management in Talangagung.

\section{METHOD}

\section{A. System Dynamics}

The systems dynamic approach is a modeling and simulation approach using the computer to analyze and create an existing system to models a new scenario on policy or system. The steps of systems dynamic begin with analyzing the main problem in a continuous system, where models consist of significant influencing variables which are identified. The identification is done until all the variables in models have covered the objectives of the study. The developed models are used as a base for the development of Stock and Flow Diagram (SFD) which simulated with the help of software and computer [9].

The simulation result using system dynamic should be verified and validated. The simulation is verified if there is no error in the process of simulation. Whereas the validation of system dynamics approach uses a method to compare the average of mean and variance. The mean comparison (E1) is done by comparing the average of the simulation generated data with the average of the actual data. The comparison is considered valid if the absolute 
value of $\mathrm{E} 1$ is less than 5\%. While the variance comparison (E2) is done by comparing the variance or standard deviation of simulation generated data and actual data, the comparison is considered valid if the absolute value of E2 is less than 30\% [10].

Furthermore, the verified and validated models are used to define new scenarios and assist the stakeholders to create a new policy or system.

\section{B. Asset Utilization}

From the perspective of industries, there is no definite term for asset utilization. However, the definition of asset utilization is about the percentage of current actual output compared to the maximum capacity of an asset. The implementation of asset utilization is required to obtain two kinds of data which are the actual output and the maximum capacity of the asset. [11]

The systems dynamic approach is capable to provide a model to optimize the asset utilization [12][13] regarding the management of the landfill zones. Hence in this research, the system dynamics method is used to predict waste volume in the next few years, besides, this method is used to manage when and how the landfill zones should be used.

\section{RESULTS AND DISCUSSION}

\section{A. Waste Degradation Periods}

Organic waste should be converted into compost, therefore it is possible to utilize the organic waste resources to recover the soil structure and richness [14]. Furthermore, it can solve any municipal waste problems and reduce the effect of waste pollution. In the process, the organic waste needs some periods to completely converted into compost. The previous study about waste degradation shows that various waste has different degradation periods as fast as 21 days to more than 7 months [15]. Table 1 shows the time period of degradation in some organic waste.

The study of waste degradation periods is used as references in the modeling and simulation of the waste replacement in landfill zone. To simulating the municipal waste replacement periods in landfill zone, need to calculate how long the period of waste converted into compost beforehand.

\section{B. Prediction of Yearly Waste Volume}

The study conducted by Adipraja and Islamiyah has predicted the municipal waste volume up to 20 years. The sources of the waste have been identified which are from residents, hospitals, markets, industries, and public facilities [4].

Figure 1 shows the prediction graph on waste volume which sent to Talangagung landfill. The study predicts that the waste volume will increase by about $42 \%$ per 5 years, in other words, it is increasing up to $8.4 \%$ per year.

The details of the waste volume prediction which can be seen in Table 2, shows that the significant increase in waste volume generation soon or later will affect the landfill management. It will approximately beyond the capacity of the landfill in around 2026, the capacity of the landfill can be seen in Table 3 .

\section{Zones Management}

The waste in Talangagung needs to be processed beforehand to separate between organic and non-organic waste. Non-organic waste will be recycled, while the organic waste is buried in landfill zone and start producing biogas until it converted into compost.

Figure 2 shows only the organic waste which is buried in Talangagung landfill. The common ratio of municipal organic waste is $48-70 \%$, but in talangagung, the ratio is up to $53 \%$ comparing with non-organic waste [1].

Organic waste in landfill zone will be buried until the zone is fully occupied, then settled in some period of degradation. After that period, the waste which already been processed into compost needs to excavated and replaced with a new waste. Figure 2 shows the organic waste buried into landfill and later will replace with a new waste after some period of degradation.

Talangagung landfill has a total land area of 4.6 hectares including 4 dumping zones which shows in Figure 3. There are 3 zones with a land area of 0.7 hectares each, and a zone with a land area of 0.4 hectares. The sanitary landfill methods are used to manage the zones, therefore the zone needs to be dug as deep as 10 meters. Waste dumped into the zone is separated every 3 meters with gravel and soil, while the thickness of the separator is about half meters.

As mention before in Figure 3, Talangagung landfill has 4 dumping zones. The capacity of Zone 1, Zone 2, and Zone 3 each are about $59.000 \mathrm{~m}^{3}$. The capacity of Zone 4 is the smallest compared to another zone which is just about $34,000 \mathrm{~m}^{3}$. For this research, the model is summing up all the capacity to about $212,500 \mathrm{~m}^{3}$. Detail of the model can be seen in Figure 4 and the details can be seen in Table 3 .

The first step, the model will process begin with dumping all the organic waste to Zone 1 . The second step, the waste will accumulate through the year. If the utilization of Zone 1 is full or reaches $100 \%$, then the rest of the waste accumulates in the variable of Zone 1 Overload. If Zone 1 in full utilization, it will be settled for about 7 months of the period of degradation, and about 5 months to excavate the completely degraded waste or compost and refill the zone with a new organic waste. This process will repeat from the beginning. The detail of the process can be seen in Figure 5.

The Fill Level Accumulator is used to determine the utilization of a Landfill Zone which gets the waste supply from "waste filling" variable each year. The utilization models use the "if then else" equations that expressed in pairwise preference which can be seen on equation 1 . This equation is used in zone 1 to zone 4 Fill Level Accumulator. However, in zone 2 to 4, it uses the overload amount of the previous zone to fill the "waste filling" variable.

$$
\begin{aligned}
f(x) & =\left\{\begin{aligned}
a-c, \text { if } a>b \\
d, \text { if } a \leq b
\end{aligned}\right. \\
a & =\text { Fill Level Accumulator } \\
b & =\text { Zone Capacity } \\
c & =\text { Landfill Replacement/Dismantle } \\
d & =\text { Waste Filling }
\end{aligned}
$$

From the simulation, the result shows that the Zone 1 can accommodate the first 4 year that is 2000 until 2003. The simulation result which for a fifth year or in 2004, the zone will full capacity with some overloaded waste 
about $8900 \mathrm{M}^{3}$. So the management needs another zone to be active and send the overloaded waste start for the fifth year. The Detail of simulation result can be seen in from the simulation in Zone 2, this zone is active when the waste accumulation in zone 1 was overload. Same as Zone 1 , the waste is accumulated through the year. When the utilization of Zone 2 is full or reach $100 \%$, the rest of the waste accumulated in the variable of Zone 2 Overload. If Zone 2 in full utilization, it will be settled for about 7 months of the period of degradation, and about 5 months to excavate the completely degraded waste or compost and refill the zone with a new organic waste. This process will repeat from the beginning. The detail of the process can see in Figure 6.

From the simulation, the result is Zone 2 can accommodate until 2016. So, there is no reason to activate the third zone. Depend on the simulation result, from 2004 the first and second landfill zones used simultaneously. The detail of the simulation result can be seen on Table 5.

Form the theory, the Zone 3 is activated when the waste accumulated in zone 2 is overloaded. Same as the previous zone, the waste is accumulated through the year. If the utilization of zone 3 is full $(100 \%)$ then the rest of the waste accumulated in the variable of Zone 3 Overload. If zone 3 in full utilization, it will be settled for about 7 months of the period of degradation, and about 5 months to excavate the completely degraded waste or compost and refill the zone with a new organic waste. This process will repeat from the beginning. The graph of the utilization models of zone 3 can be seen in Figure 7.

From the previous simulation result, it has no reason to activate the third zone. From the year 2004, the first and second landfill zones used simultaneously and there is no overloaded data from the usage of the third zone until 2016.

The Zone 4 is activated when the waste accumulated in zone 3 is overloaded. The waste also will accumulate through the year. If the utilization of zone 4 is full (100\%) then the rest of the waste accumulated in the variable of Zone 4 Overload. If Zone 4 in full utilization, it will be settled for about 7 months of the period of degradation, and about 5 months to excavate the completely degraded waste or compost and refill the zone with a new organic waste. This process will repeat from the beginning. The utilization model of Zone 4 is can see in Figure 8.

Depend on the previous simulation, from the year of 2004 the first and second landfill zones used simultaneously and there is no overloaded data from the usage until 2016. So, that it has no reason to activate the fourth zone.

The organic waste which already been degraded and converted to compost should be excavated and replaced with a new organic waste. The processed waste then reduces the amount of waste in the landfill which affecting the accumulated waste on the landfill site. The model which detailing the accumulate process waste can be seen in Figure 9.

\section{Validation}

A model needs to be tested before use for the prediction process. To see the validity of the simulation results comparing with the existing data, the model simulation results that have been made need to be measured the error rate using the mean comparison (E1) and the variance comparison (E2). The validated simulation result is the volume of waste delivered to Talangagung landfill in which the formula can be seen in detail in Table 6.

Form the calculation of validation, the result of this study has been considered valid with error rate E1 of $2.33 \%$ and E2 of $0.76 \%$. Therefore, this scenario results can be used to optimize the use of the landfill zone.

\section{E. Prediction of Zones Utilization}

The model that has been verified and validated is used to predict the future of the utilization status of landfill zones. The predictions of the model of zone 1 which we can see in Figure 5 shows that zone 1 is always active and always have an overloaded waste every year. Table 7 shows the prediction of the utilization of zone 1 which will get at max capacity. From this table, we can conclude that it is impossible for Talangagung to manage the accumulated waste just using a zone. Furthermore, the utilization prediction chart of the zone 1 can be seen on Figure 10.

The prediction of the model of zone 2 which we can see in Figure 6 shows that zone 2 is always active and always have an overloaded waste every year starting from 2018. Table 8 shows the prediction of the utilization of zone 2 which will get at the max capacity start from 2018. From this table, we can conclude that it is also impossible for Talangagung to manage the accumulated waste just using 2 zones start from 2018. Furthermore, the utilization prediction chart of the zone 2 can be seen on Figure 11.

The prediction of the model of zone 3 which we can see in Figure 7 shows that zone 3 is starting to activate from the year 2018. Table 9 shows the prediction of the utilization of zone 3 which will get at the max capacity start from 2025. From this table, we can conclude that it is also impossible for Talangagung to manage the accumulated waste just using three zone starts from 2025. Furthermore, the utilization prediction chart of the zone 3 can be seen on Figure 12.

The prediction of the model of zone 4 which we can see in Figure 8 shows that zone 4 is starting to activate from the year 2025. However, Table 10 shows the prediction of the utilization of zone 4 which will get at the max capacity start from 2026. The zone 4 is not helping much because of its small capacity. Therefore, it is also impossible for Talangagung to manage the accumulated waste even using all the landfill zone in 2026 and later. Furthermore, the utilization prediction chart of the zone 4 can be seen on Figure 13.

There is need another landfill zone to accommodate the overloaded waste in 2026. It is advisable to use unused land on the site or buy new land around the site.

\section{CONCLUSION}

The previous study about waste volume over the next 20 years shows that the increased amount of waste volume soon or later will exceed the current capacity of landfill zones. The current management of landfill zones used sanitary landfill which settled the waste in zones in some periods. 
The previous study shows that the time period of degradation in various waste is as fast as 21 days to more than 7 months. Hence, this simulation uses 1 year assumption to accomplish the degradation and the waste replacement in a zone. The models in this study were validated with a mean error of about $2.33 \%$ (E1) and the variance error of about $0.76 \%$ (E2).

The simulation of the models shows that around 2004 it requires 2 landfill zones to use in parallel. Hereafter, the prediction shows not only in the year 2018 the landfill requires 3 zones used simultaneously, but also in the year 2025 necessarily to use 4 zones simultaneously.

Moreover, based on the simulation result, it is predicted that the overload of landfill capacity will occur

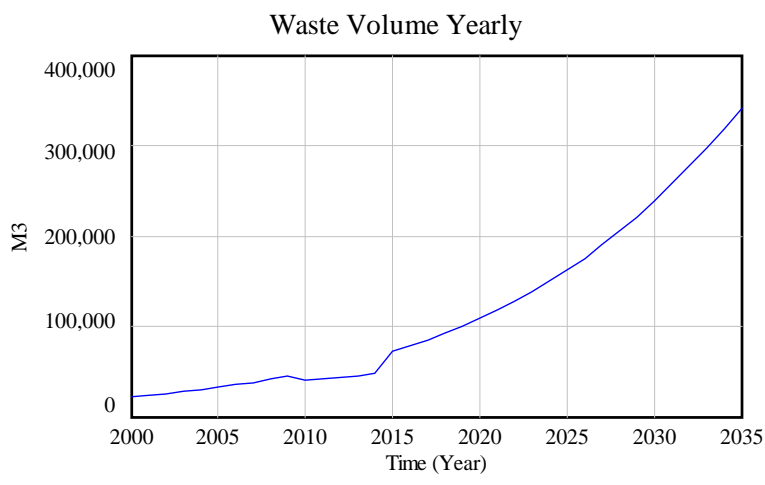

Waste Volume Yearly : Current

Figure 1. Prediction of waste volume on Talangagung Landfill.[4]

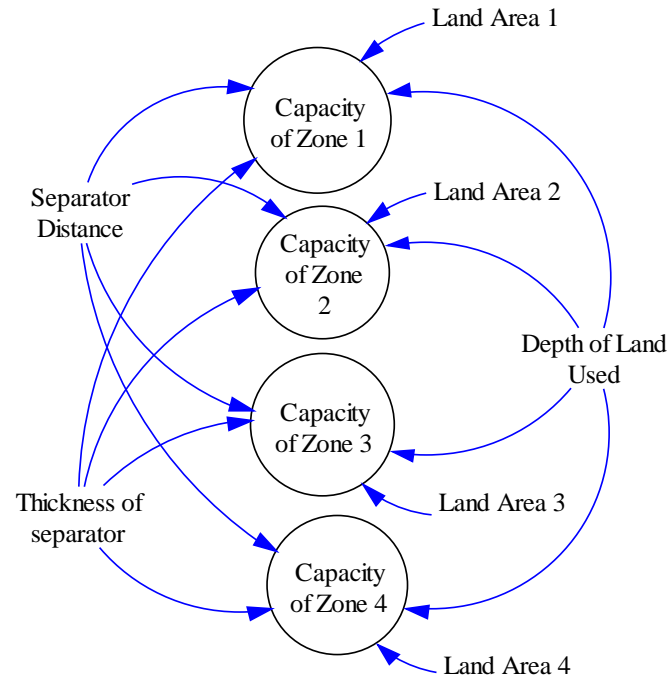

Figure 3. Models of landfill zones capacity.

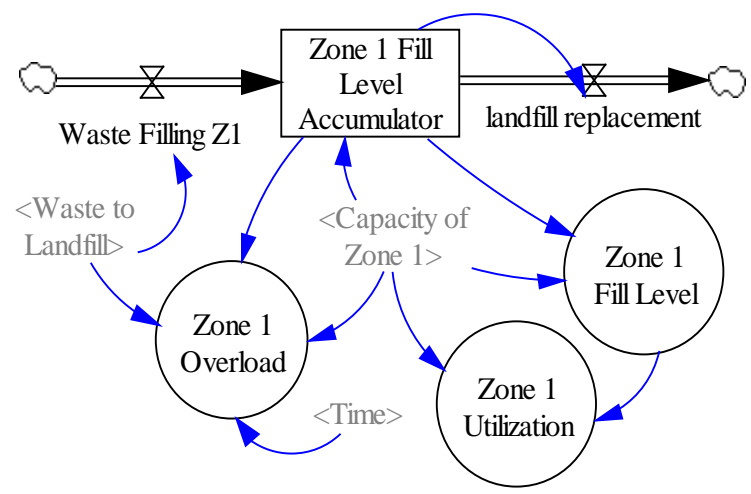

Figure 5. Utilization models of zone 1. in the year 2026. Therefore, to accommodate the overloaded waste, it is advisable to use the idle lands on the site or expand by buying the land around the site.

\section{ACKNOWLEDGMENTS}

The research for this paper was financially supported by research grants of Research Lecturers for Beginners (PDP) given by the Indonesian Ministry of Research, Technology and Higher Education (RISTEKDIKTI). Moreover, the work of this study was supported by Department of Human Settlements and Spatial Planning and Development of Malang Regency (Dinas Cipta Karya dan Tata Ruang Kab. Malang).

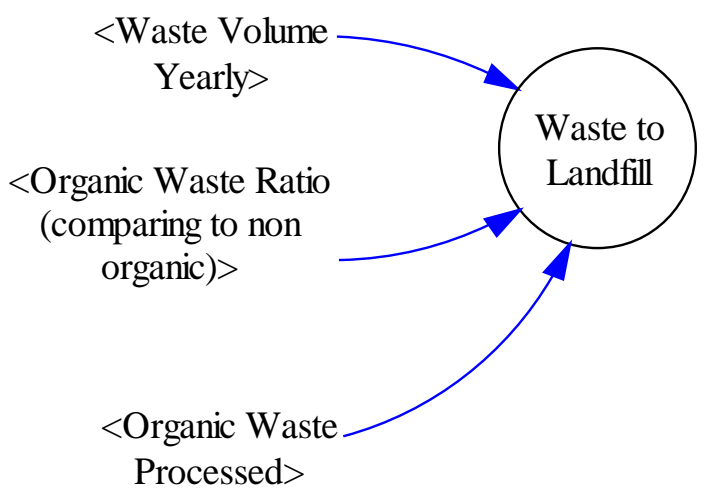

Figure 2. The models of organic waste ratio to landfill.

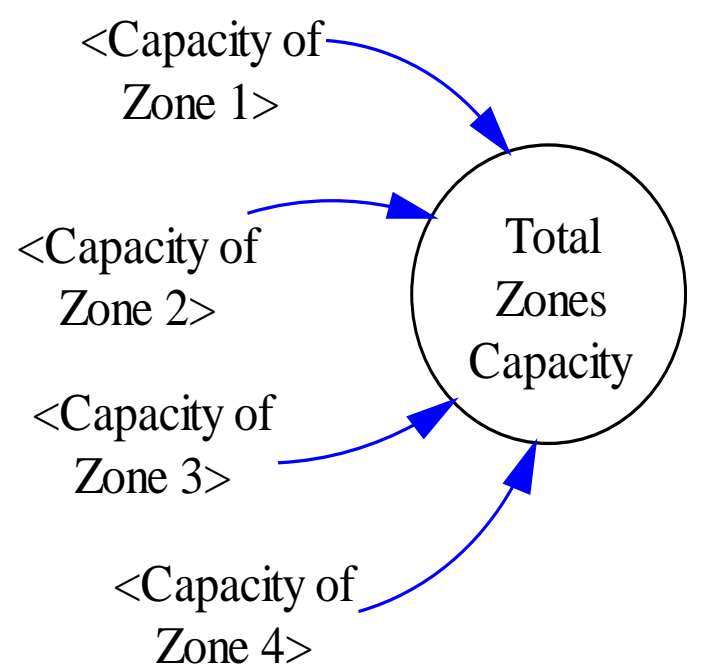

Figure 4. Models of total zones capacity.

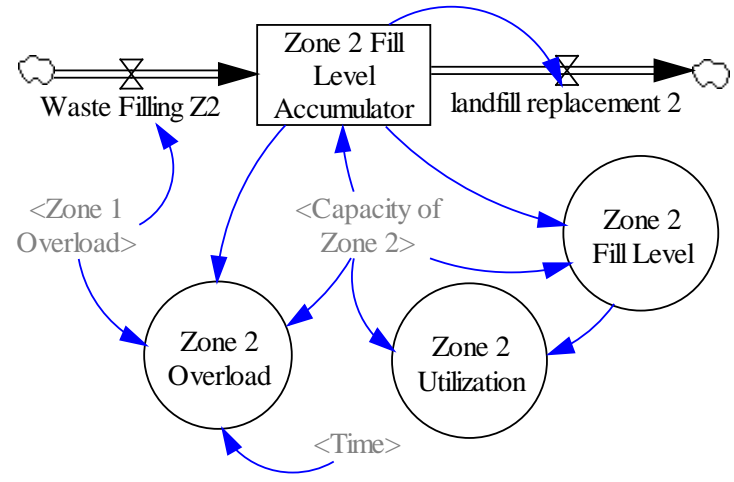

Figure 6. Utilization models of zone 2. 


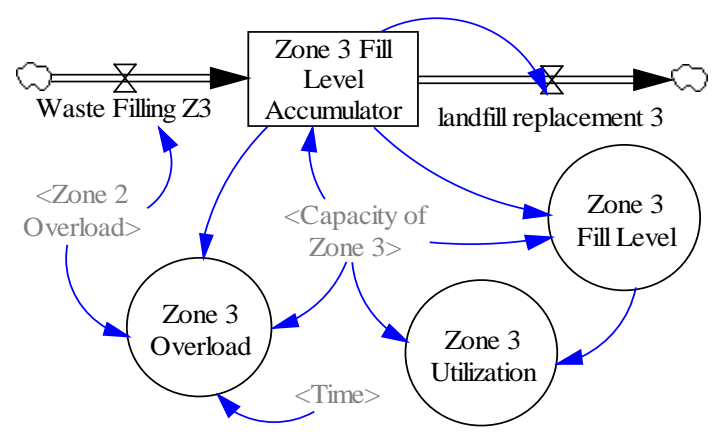

Figure 7. Utilization models of zone 3.

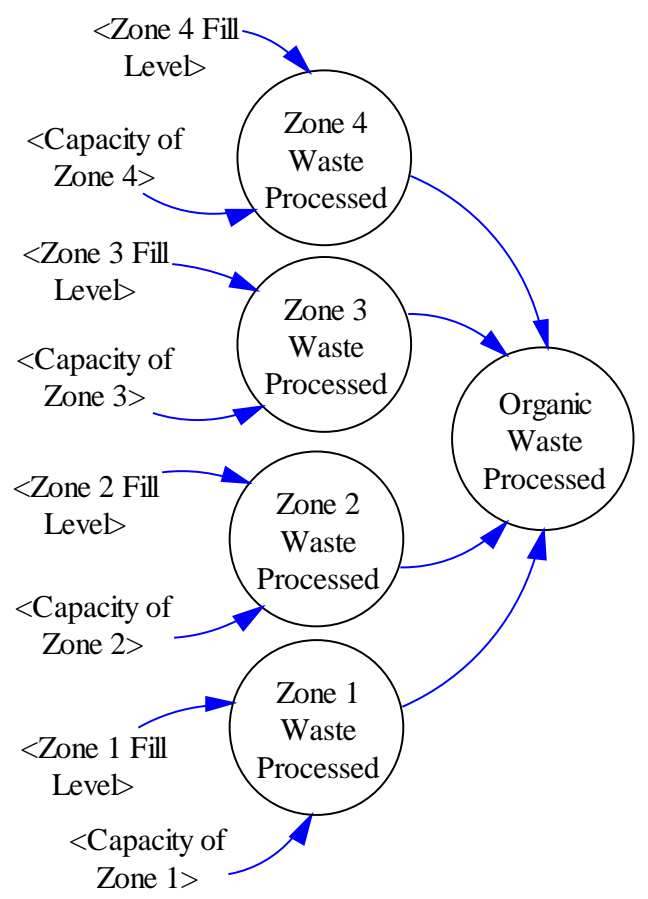

Figure 9. The model of processed waste.

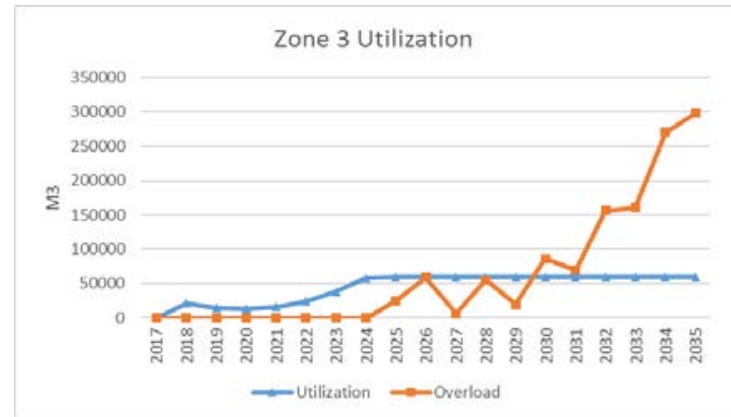

Figure 12. Utilization graph of zone 3.

TABLE 1.

TIME PERIOD of Degradation of Different Agro-INDUSTRIAL WASTE [15]

\begin{tabular}{llc}
\hline \hline$\#$ & \multicolumn{1}{c}{ Agro-Industrial waste } & Time period of degradation \\
\hline 1. & Cattle manure & 55 days \\
2. & Source segregated household waste & 112 days \\
3. & Municipal organic Waste & 120 days \\
4. & Mixtures of dairy manure & 56 days \\
5. & Kitchen waste & 21 days \\
6. & Water hyacinth & 210 days \\
7. & Spinach waste & 79 days \\
8. & Biosolids & 28 days \\
9. & Sludge & 150 days \\
10. & sugar-cane waste by-products & 70 days \\
11. & Wheat straw & 70 days \\
\hline \hline
\end{tabular}

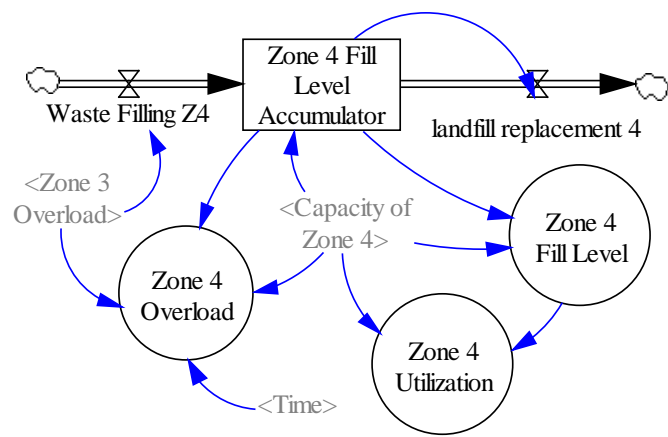

Figure 8. Utilization models of zone 4.

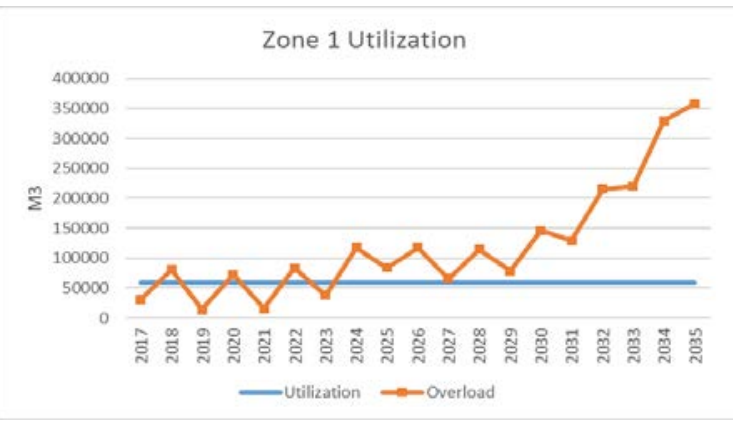

Figure 10. Utilization graph of zone 1.

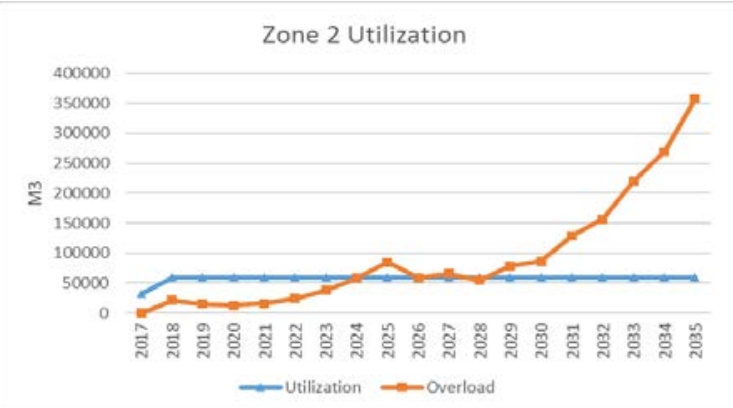

Figure 11. Utilization graph of zone 2.

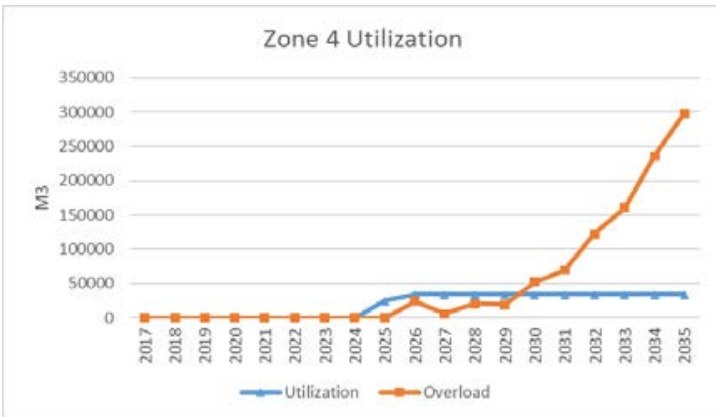

Figure 13. Utilization graph of zone 4 .

TABLE 2.

Prediction On WAste Volume Generation in MALANG [4]

\begin{tabular}{rrrr}
\hline \hline \multirow{2}{*}{ Year } & \multirow{2}{*}{ Populations } & \multicolumn{2}{c}{ Waste Volume in Talangagung } \\
\cline { 3 - 4 } & & $\mathbf{( M}^{3}$ per year $)$ & $\mathbf{~}^{3}$ per day) \\
\hline 2016 & 3.420 .442 & $78.629,13$ & 215,42 \\
2025 & 3.652 .133 & $162.226,92$ & 444,45 \\
2026 & 3.678 .827 & $175.488,23$ & 480,78 \\
2035 & 3.928 .021 & $341.341,19$ & 935,18 \\
2036 & 3.956 .731 & $365.127,72$ & 1000,34 \\
\hline \hline
\end{tabular}


TABLE 3.

THE CAPACITY OF EACH ZONE IN TALANGAGUNG LANDFILL

\begin{tabular}{rc}
\hline \hline Descriptions & Capacity $\left(\mathbf{M}^{3}\right)$ \\
\hline Zone 1 & 59,500 \\
Zone 2 & 59,500 \\
Zone 3 & 59,500 \\
Zone 4 & 34,000 \\
Total Capacity & 212,500 \\
\hline \hline
\end{tabular}

TABLE 5.

UTILIZATION AND OVERLOAD STATUS OF ZONE 2

\begin{tabular}{ccc}
\hline \hline Time (Year) & Zone 2 Utilization & Zone 2 Overload $\mathbf{( M}^{3}$ ) \\
\hline 2000 & $0.0 \%$ & - \\
2001 & $0.0 \%$ & - \\
2002 & $0.0 \%$ & - \\
2003 & $0.0 \%$ & - \\
2004 & $15.0 \%$ & - \\
$\ldots$ & $\ldots$ & $\ldots$ \\
$\ldots$ & $\ldots$ & $\ldots$ \\
2012 & $12.3 \%$ & - \\
2013 & $52.7 \%$ & - \\
2014 & $0.0 \%$ & - \\
2015 & $7.0 \%$ & - \\
2016 & $77.1 \%$ & - \\
\hline \hline
\end{tabular}

TABLE 7.

Prediction of Utilization AND OVERLOAd Status OF Zone 1

\begin{tabular}{ccc}
\hline \hline Time (Year) & Zone 1 Utilization & Zone 1 Overload $\left(\mathbf{M}^{3}\right)$ \\
\hline 2017 & $100.0 \%$ & $31,553.63$ \\
2018 & $100.0 \%$ & $80,571.77$ \\
2019 & $100.0 \%$ & $14,728.17$ \\
2020 & $100.0 \%$ & $72,363.58$ \\
2021 & $100.0 \%$ & $15,842.28$ \\
$\ldots$ & $\ldots$ & $\ldots$ \\
$\ldots$ & $\ldots$ & $\ldots$ \\
2031 & $100.0 \%$ & $128,730.82$ \\
2032 & $100.0 \%$ & $215,691.48$ \\
2033 & $100.0 \%$ & $220,060.09$ \\
2034 & $100.0 \%$ & $329,415.49$ \\
2035 & $100.0 \%$ & $357,326.31$ \\
\hline \hline
\end{tabular}

TABLE 9.

PREDICTION OF UTILIZATION AND OVERLOAd STATUS OF ZONE 3

\begin{tabular}{ccc}
\hline \hline Time (Year) & Zone 3 Utilization & Zone 3 Overload $\mathbf{( M}^{3}$ ) \\
\hline 2017 & $0.0 \%$ & - \\
2018 & $35.4 \%$ & - \\
$\ldots$ & $\ldots$ & $\ldots$ \\
2024 & $97.2 \%$ & - \\
2025 & $100.0 \%$ & $24,824.68$ \\
2026 & $100.0 \%$ & $58,333.44$ \\
$\ldots$ & $\ldots$ & $\ldots$ \\
2031 & $100.0 \%$ & $69,230.82$ \\
2032 & $100.0 \%$ & $156,191.48$ \\
2033 & $100.0 \%$ & $160,560.09$ \\
2034 & $100.0 \%$ & $269,915.49$ \\
2035 & $100.0 \%$ & $297,826.31$ \\
\hline \hline
\end{tabular}

TABLE 4.

UTILIZATION AND OVERLOAD STATUS OF ZONE 1

\begin{tabular}{ccc}
\hline \hline Time (Year) & Zone 1 Utilization & Zone 1 Overload $\mathbf{( M}^{3}$ ) \\
\hline 2000 & $19.6 \%$ & - \\
2001 & $40.7 \%$ & - \\
2002 & $63.5 \%$ & - \\
2003 & $88.3 \%$ & - \\
2004 & $100.0 \%$ & $8,911.25$ \\
$\ldots$ & $\ldots$ & $\ldots$ \\
$\ldots$ & $\ldots$ & $\ldots$ \\
2012 & $100.0 \%$ & $7,343.28$ \\
2013 & $0.0 \%$ & $31,365.94$ \\
2014 & $42.5 \%$ & - \\
2015 & $100.0 \%$ & $4,182.39$ \\
2016 & $0.0 \%$ & $45,855.83$ \\
\hline \hline
\end{tabular}

TABLE 6.

SISTEM DYNAMICS VALIDATION ON WASTE VOLUME GENERATION

\begin{tabular}{ccc}
\hline \hline Type of Validation & Result & Status \\
\hline Mean Comparison & $\frac{|40,221-39,306|}{40,221}$ & Valid \\
$E 1=\frac{\mid \bar{S}-\bar{A}]}{\bar{A}}$ & $=0.02328 \times 100 \%=2,33 \%$ & \\
$(<5 \%)$ & $\frac{|15,346-15,463|}{15,463}$ & Valid \\
Error Variance & \\
$E 2=\frac{|S s-S a|}{S a}$ & $=0.0076 \times 100 \%=0.76 \%$ & \\
$(<30 \%)$ & \\
\hline \hline
\end{tabular}

TABLE 8.

Prediction of Utilization AND OVERload Status of Zone 2

Time (Year) Zone 2 Utilization Zone 2 Overload $\left(\mathbf{M}^{3}\right)$

$2017 \quad 53.0 \%$ -

$2018 \quad 100.0 \% \quad 21,071.77$

$2019 \quad 100.0 \% \quad 14,728.17$

$2020 \quad 100.0 \% \quad 12,863.58$

$2021 \quad 100.0 \% \quad 15,842.28$

$\cdots \quad \cdots$

$\begin{array}{lll}\cdots & \cdots & \cdots\end{array}$

$2031 \quad 100.0 \% \quad 128,730.82$

$2032 \quad 100.0 \% \quad 156,191.48$

$2033 \quad 100.0 \% \quad 220,060.09$

$2034 \quad 100.0 \% \quad 269,915.49$

$2035 \quad 100.0 \% \quad 357,326.31$

TABLE 7.

Prediction OF Utilization AND OVERLOAd StATUS OF ZONE 4

\begin{tabular}{ccc}
\hline \hline Time (Year) & Zone 4 Utilization & Zone 4 Overload $\mathbf{( M}^{\mathbf{3}}$ ) \\
\hline 2017 & $0.0 \%$ & - \\
2018 & $0.0 \%$ & - \\
2019 & $0.0 \%$ & - \\
$\ldots$ & $\ldots$ & $\ldots$ \\
2024 & $0.0 \%$ & - \\
2025 & $73.0 \%$ & - \\
2026 & $100.0 \%$ & $24,333.44$ \\
2027 & $100.0 \%$ & $5,878.08$ \\
$\ldots$ & $\ldots$ & $\ldots$ \\
2033 & $100.0 \%$ & $160,560.09$ \\
2034 & $100.0 \%$ & $235,915.49$ \\
2035 & $100.0 \%$ & $297,826.31$ \\
\hline \hline
\end{tabular}




\section{REFERENCES}

[1] P. F. E. Adipraja, M. Islamiyah, and I. Wahyuni, "Prediksi Produksi Biogas Tahunan Dengan Pendekatan Sistem Dinamik Untuk Optimasi Kapasitas Sampah TPAS Talangagung (Prediction of Annual Biogas Production With System Dynamic Approach to Optimize The TPAS Talangagung Capacity)," in Seminar Nasional Inovasi Teknologi, 2017, vol. 1, no. 1, pp. 385-390.

[2] DCKTR, Profil TPA Wisata Edukasi Talangagung Kepanjen Kabupaten Malang (Profile of The Tourism Education of TPA Talangagung Kepanjen Malang Regency). Malang: Dinas Cipta Karya dan Tata Ruang, 2014.

[3] A. S. Suryani, "Jalan Terjal Bersihkan Negeri (Rough Roads to Clean The Country),” Aspirasi, vol. 6, no. 1, pp. 93-103, 2015.

[4] P. F. E. Adipraja and M. Islamiyah, "Prediksi Volume Sampah TPAS Talangagung dengan Pendekatan Sistem Dinamik (Prediction of Waste Volume of TPAS Talangagung: A Systems Dynamic Approach)," SMATIKA J., vol. 6, no. 02, pp. 24-28, 2016.

[5] R. A. G. I. Sumantri and E. S. Pandebesie, "Potensi Daur Ulang dan Partisipasi Masyarakat Dalam Pengelolaan Sampah di Kecamatan Jabon, Kabupaten Sidoarjo (Potential of Recycling and Public Participation in Waste Management in Jabon Subdistrict, Sidoarjo Regency)," J. Tek. ITS, vol. 4, no. 1, pp. D11D15, 2015.

[6] C. Wang, "System dynamics simulation on municipal solid waste in Hong Kong," Proc. Inst. Civ. Eng. - Munic. Eng., pp. $1-11,2017$.

[7] I. A. Al-Khatib, D. Eleyan, and J. Garfield, "A System Dynamics Model to Predict Municipal Waste Generation and Management Costs in Developing Areas,” J. Solid Waste Technol. Manag., vol. 41, no. 2, pp. 109-120, 2015.
[8] S. Goel, V. P. Ranjan, B. Bardhan, and T. Hazra, "Forecasting Solid Waste Generation Rates," in Modelling Trends in Solid and Hazardous Waste Management, Springer, 2017, pp. 35-64.

[9] G. P. Richardson, "System Dynamics," in Encyclopedia of Operations Research and Management Science, 3rd ed., S. I. Gass and M. C. Fu, Eds. New York: Springer, 2013, pp. 15191521.

[10] Y. Barlas, "Formal aspects of model validity and validation in system dynamics,” Syst. Dyn. Rev., vol. 12, no. 3, pp. 183-210, 1996.

[11] R. P. Ellis, "Asset Utilization : A Metric for Focusing Reliability Efforts," in Seventh International Conference on Process Plant Reliability, 1998, pp. 1-10.

[12] W. N. Cahyo, K. El-Akruti, R. Dwight, and T. Zhang, "Managing Maintenance Resources for Better Asset Utilisation,” Aust. J. Multi-Disciplinary Eng., vol. 11, no. 2, pp. 123-134, Jan. 2015.

[13] E. Suryani, R. A. Hendrawan, P. F. E. Adipraja, and L. P. Dewi, "A Simulation Model for Strategic Planning in Asset Management of Electricity Distribution Network," 4th Int. Conf. Soft Comput. Intell. Syst. Inf. Technol., vol. 516, pp. 539-550, 2015.

[14] A. M. Taiwo, "Composting as A Sustainable Waste Management Technique in Developing Countries,” no. September. 2011.

[15] A. Patidar, R. Gupta, and A. Tiwari, "Enhancement of BioDegradation of Bio-Solids Via Microbial Inoculation in Integrated Composting and Vermicomposting Technology," 2012 